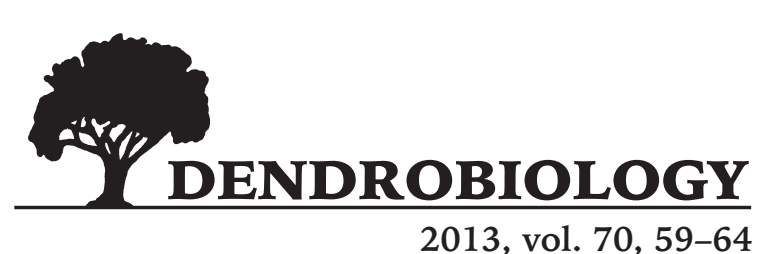

http://dx.doi.org/10.12657/denbio.070.006

\author{
Ireneusz Ochmian, Marcin Kubus, Agnieszka Dobrowolska
}

\title{
Description of plants and assessment of chemical properties of three species from the Amelanchier genus
}

Received: 30 July 2012; Accepted 16 January 2013

\begin{abstract}
Recently, the cultivation of plants combining decorative and utilitarian qualities has been gaining in popularity. These plants give tasty fruits of high biological value. Saskatoon is little known in Poland. It is mainly used as an ornamental plant for its flowers and leaves that change colour.

The aim of the study was to characterise three species of plants of Amelanchier (A. alnifolia, A. ovalis, A. spicata). The plants grown in the Research Stations (Danowo and Rajkowo), located near Szczecin, were examined with respect to the size and colour of their leaves and fruit quality; size, firmness, chemical composition, particularly with regard to the content of bioflavonoids.

It was found that Saskatoon fruits had very low acidity and vitamin C content. A. ovalis had the smallest fruits with the highest content of polyphenols. A. spicata was characterised by the smallest and greenest leaves and relatively big, firm fruits with high extract content and low content of polyphenols and organic acids.

The plants of the examined plant species of Amelanchier are suitable for cultivation in Szczecin and do not indicate any frost damage nor symptoms of disease or pest infestation. The fruits are valuable source of polyphenols and, due to their low content of organic acids, have a mild flavour. The above qualities make them suitable for consumption in the raw state, as distinguished from chokeberries that are very similar in appearance.
\end{abstract}

Additional key words: leaf, fruits quality, chemical compositions, phenolics

Addresses: I. Ochmian, A. Dobrowolska, West Pomeranian University of Technology in Szczecin, Department of Horticulture, Słowackiego 17, 71-434 Szczecin, Poland, e-mail: ireneusz.ochmian@zut.edu.pl, ochir@o2.pl, agdobrowolska@zut.edu.pl, M. Kubus, West Pomeranian University of Technology in Szczecin, Department of Dendrology and Landscape Architecture, Papieża Pawła VI 3, 71-459 Szczecin, Poland

\section{Introduction}

The genus Amelanchier (Rosaceae) is represented by about 25 species that are found in North America and in parts of Europe and Asia (Adhikari et al. 2005). The Pacific serviceberry (A. alnifolia), Canadian serviceberry (A. canadensis), juneberry (A. lamarckii), snowy mespilus (A. ovalis) are rare in Poland. Dwarf serviceberry (A. spicata) also occurs in North America and Asian serviceberry occurs in Asia.
The systematics of the Amelanchier genus appears as follows:

Subclass Rosidae

Order Rosales

Family Rosaceae - Roses

Genus Amelanchier Medik. - Serviceberry

Amelanchier alnifolia Nutt. - commonly referred to as saskatoon berry, serviceberry, or Juneberry - is a fruit bearing shrub native to the southern Yukon and Northwest Territories, the Canadian prairies and the 
northern plains of the United States (Mazza and Davidson 1993). An individual bush may bear fruit 30 or more years. Saskatoons are adaptable to most soil types with exception of poorly drained (mildly alkaline) (Finn 1999) or heavy clay soils lacking organic matter. Its dark-purple, berry-like pome fruit range in diameter from 10 to $15 \mathrm{~mm}$ on average, depending on the cultivar (Zatylny et al. 2002). The Pacific serviceberry was used by Indians to produce pemmican and its fruits were men's favourite snack. Dried berries were used to make desserts and twigs were used to make tea (Łuczaj 2004).

Amelanchier ovalis naturally occurs in Central and Southern Europe, Asia Minor and along the north coast of Africa. According to literature data, it occurred in the western region of the Tatra Mountains; however, it was not found there after World War II (Seneta 1991). The snowy mespilus is frequently confused with other species of this genus. The basic diagnostic feature of snowy mespilus are flowers with short-styled pistils, which do not exceed the height of the calyx and are not grown together. Bushes reach the height from 1.5 to $3 \mathrm{~m}$, usually with rigidly straightened branches and shoots (Seneta 1991). Shoots are initially covered with white hair and ovate leaves are 2.5 to $5 \mathrm{~cm}$ long, rounded at both ends and serrate. Fruits are small with protruding segments, with navy-blue and black coating, juicy, edible despite the fact that their flavor is bland, due to a low acid content.

Amelanchier spicata - dwarf serviceberry - occurs naturally in north-eastern North America (mostly in the USA). A. spicata is fully naturalised in Western Europe and is commonly found from England to Sweden (Binggeli 1988). It is a low bush (0.5-2 m) with numerous shrub-forming shoots. The leaves are 2.5-5 $\mathrm{cm}$ long, they are roundish or broadly ovate, pointed, serrate, with white felted bottom during bloom. The flowers are white or slightly pinkish, up to $10 \mathrm{~mm}$ long, in long, thick clusters. The fruits are navy blue and white, juicy and sweet. Soil and environmental requirements as well as the applications are similar to the Pacific serviceberry. A. spicata is very resistant to low temperatures, to about -40 to $-50^{\circ} \mathrm{C}$ (Pirs 2000). It has been present in Poland since 1820. It is mostly used as an ornamental plant, but its fruits are also collected in some countries (Kuusk et al. 1996).

Serviceberries are species closely related to each other and difficult to distinguish due to considerable foliage variability. Additionally, interspecies hybrids can be encountered, which make precise identification even more difficult. Trees can be used as ornamental plants, both due to their white flowers, dark pink fruits and autumn red and purple courses of the foliage. Fruits can be eaten raw or processed. They can be used for the production of juices, jams, preserves and cordials and as an addition to other sour fruits (Mazza 2005). Berries and fruits, including Sas- katoon berries, are excellent sources of bioactive components such as anthocyanins, flavonols, procyanidins, and phenolic acids. Recently, anthocyanins along with other phenolics have attracted much interest due to their antioxidant properties and perceived health benefits, including antimicrobial, anti-inflammatory, and anticarcinogenic activities, insulin secretion ability, and neuroprotective effects (Han et al. 2007). They are also rich in dietary fibre, group B vitamins and other mineral substances, especially potassium, and micronutrients such as cobalt and copper (Mazza 1982; Mazza 2005). Fruits are a delicacy for birds. These plants are grown on a large scale in backyard gardens and in plantations (Bakowska-Barczak and Kolodziejczyk 2008), due to their high frost resistance and they are also used to establish wind protection belts (Finn 1999). In Poland, the serviceberry is not well-known or common.

The aim of this study was to compare several serviceberry species occurring in Poland in respect of morphological differences as well as the quality and chemical composition of the fruits.

\section{Plant material}

A. ovalis and A. spicata bushes grew in a nursery in Danowo of the Nowogard Forest District (northwestern Poland). They were reproduced generatively in the years 1979-1981 from seeds obtained within an exchange programme of planting material between European botanical gardens and arboreta (Kubus 2003). A. alnifolia grew at the Rajkowo Research Station belonging to the Department of Horticulture. Vegetatively reproduced plants were acquired from the Fruit Farming and Floriculture Institute in Skierniewice.

\section{Methods}

The research was conducted at the Department of Horticulture, West Pomeranian University of Technology in Szczecin in the years 2009-2011. The chlorophyll content index and the size and colour of leaves were measured in July. The measurements of fruit size and color, weight, and firmness as well as soluble solids, titratable acidity, dry matter and L-ascorbic acid content were performed in fresh berries instantaneously after the harvest.

Leaves area was measured by DIAS scanner interfaced with a computer, while the index of greening leaves, correlated with chlorophyll content (Gregorczyk and Raczyńska 1997) by Chlorophyll Meter SPAD-502 (Minolta). The color of leaves and fresh-cut fruits was directly measured with a spectrophotocolorimeter Minolta CM-700 (Konica Minolta Sensing, Inc., Osaka, Japan). The CIE L* (lightness), CIE a* (red-green) and CIE b* (yellow-blue) were read using a 
$\mathrm{D}_{75}$ light source and the observer angle at $10^{\circ}$ and consisting of a head with an $3 \mathrm{~mm}$ diameter measuring area. These measurements were made on the same leaves in 3 replicates of 50 leaves.

From the yield obtained from the tested bushes randomly collected samples for analysis (3 samples $\times$ $1 \mathrm{~kg}$ for the species). Fruit mass was measured with RADWAG WPX 4500 electronic scales (0.01 g accuracy). Fruit diameter and firmness was measured with a non-destructive computerized device FirmTech 2 (BioWorks, USA). The firmness for 100 randomly selected berries from each replicate was expressed as a gram-force causing fruit surface to bend $1 \mathrm{~mm}$.

For juice extraction efficiency fruit were homogenized with a blender and heated up to $50^{\circ} \mathrm{C}$. Then, after cooling, $1.5 \mathrm{ml}$ of pectinase (Rapidaza Super) per $500 \mathrm{~g}$ of pulp were added. The pulp was left to stand in a room temperature for 1 hour. Afterward, the pulp was pressed for $10 \mathrm{~min}$ at the final pressure of 300 kPa by means of a laboratory hydraulic press. Further, the acidity was determined by titration with $0.1 \mathrm{~N}$ $\mathrm{NaOH}$ to an end point of $\mathrm{pH} 8.1$ (measured with an Orion 720A pH meter; Orion Research Incorporated, USA). Titratable acidity was determined by potentiometric method using $\mathrm{pH}$-meter Elmetron, and expressed as equivalents of citric acid $100 \mathrm{~g}^{-1}$. Soluble solids content was determined with a digital refractometer PAL-1 (Atago, Japan). L-ascorbic acid content was measured with a RQflex 10 requantometer (Merck) and expressed as mg per $100 \mathrm{~g}$ fruit juice.

Phenolics composition of blueberries was determined in rest of fruits samples that were kept frozen $\left(-28^{\circ} \mathrm{C}\right)$ in polyethylene bags $(450-500 \mathrm{~g})$ until analyzed. The HPLC analyses of polyphenols were carried out with HPLC apparatus consisting of a Merck-Hitachi L-7455 diode array detector (DAD) and quaternary pump L-119 7100 equipped with D-7000 HSM Multisolvent Delivery System (Merck-Hitachi, Tokyo, Japan). Retention times and spectra were compared to that of pure standards and total polyphenols content was expressed as mg per $100 \mathrm{~g}$ fruit tissue.
The results obtained were subjected to statistical analysis using Statistica 9 (Statsoft, Poland). The values were evaluated by the Duncan test and the differences at $\mathrm{P}<0.05$ were considered significant.

\section{Results and discussion}

To describe the species under analysis, several parameters characterising the leaves were measured. Their size and colour were determined. It was found that the leaves of all species under analysis are characterised by a smaller diameter compared to their length, which makes their shape lanceolate. Leaves of A. alnifolia and A. ovalis were larger than A. spicata, they were also the broadest and the longest (Table 1). Also, the colour of the leaves was measured. It was shown that the upper side of the blade of all three species of the serviceberry is darker than the bottom. From among the species under analysis, A. alnifolia had the lightest leaves (parameter $\mathrm{L}^{*}$ - bottom 61.2; top 49.6), while $A$. ovalis (Table 1) had the darkest ones. The upper leaf surface of all species is also noticeably greener or more yellow than the bottom (Table 1). It was found that A. spicata was characterised by the greenest top side of the leaves and it was also slightly more yellow compared to other species $\left(b^{*}\right)$. The lowest values of $\mathrm{a}$ and $\mathrm{b}$ parameters were found in the $A$. ovalis species in which also the lowest chlorophyll content index was recorded. The chlorophyll content index is highly correlated with the chlorophyll content, which is responsible for the green colour (Pacewicz and Gregorczyk 2009). This is confirmed by the results of our experiment too, leaves with high values of the chlorophyll content index were also characterised by the highest green colour index (parameter $\mathrm{a}^{*}$ ).

The size of fruits, apart from their taste and nutritional value, is one of the most important characteristics which consumers pay attention to. There were significant differences between Amelanchier species under analysis as far as the size of fruit is concerned (Table 2). A. ovalis berries were characterised by the lower weight of 100 fruits (56 g), and at the same

Table 1. Characteristic of leaves of tested species of Amelanchier

\begin{tabular}{|c|c|c|c|c|c|c|c|c|}
\hline \multirow{2}{*}{\multicolumn{2}{|c|}{ Items }} & & \multicolumn{6}{|c|}{ Species } \\
\hline & & & \multicolumn{2}{|l|}{ A. alnifolia } & \multicolumn{2}{|c|}{ A. ovalis } & \multicolumn{2}{|c|}{ A. spicata } \\
\hline \multicolumn{3}{|c|}{ Leaves area $\left(\mathrm{cm}^{2}\right)$} & \multicolumn{2}{|l|}{$8.95 \mathrm{~b}$} & \multicolumn{2}{|c|}{$7.63 \mathrm{~b}$} & \multicolumn{2}{|c|}{$5.27 \mathrm{a}$} \\
\hline \multicolumn{3}{|c|}{ Diameter of leaves $(\mathrm{cm})$} & \multicolumn{2}{|l|}{$3.1 \mathrm{~b}$} & \multicolumn{2}{|c|}{$3.2 \mathrm{~b}$} & \multicolumn{2}{|c|}{$2.4 \mathrm{a}$} \\
\hline \multicolumn{3}{|c|}{ Length of leaves $(\mathrm{cm})$} & \multicolumn{2}{|l|}{$4.6 \mathrm{~b}$} & \multicolumn{2}{|c|}{$3.7 \mathrm{ab}$} & \multicolumn{2}{|c|}{$3.1 \mathrm{a}$} \\
\hline \multicolumn{3}{|c|}{ Green index of leaves (SPAD) } & $54.4 \mathrm{~b}$ & & \multicolumn{2}{|c|}{$48.3 \mathrm{a}$} & \multicolumn{2}{|c|}{$61.2 \mathrm{c}$} \\
\hline \multicolumn{3}{|c|}{ Leaves color } & $\begin{array}{l}\text { bottom } \\
\text { of leaf }\end{array}$ & top of leaf & $\begin{array}{c}\text { bottom } \\
\text { of leaf }\end{array}$ & top of leaf & $\begin{array}{c}\text { bottom } \\
\text { of leaf }\end{array}$ & top of leaf \\
\hline $\mathrm{L}^{*}$ & black 0 & white 100 & 61.2 & 49.6 & 31.7 & 25.6 & 49.8 & 34.5 \\
\hline$a^{*}$ & red +100 & green -100 & -3.99 & -4.85 & -3.13 & -3.79 & -2.89 & -5.83 \\
\hline $\mathrm{b}^{*}$ & yellow +100 & blue -100 & 22.33 & 16.65 & 8.91 & 8.97 & 14.13 & 21.65 \\
\hline
\end{tabular}

Explanation: The means signed with the same letter do not differ significantly at the $5 \%$ level of significance, according to Duncan t-test. 

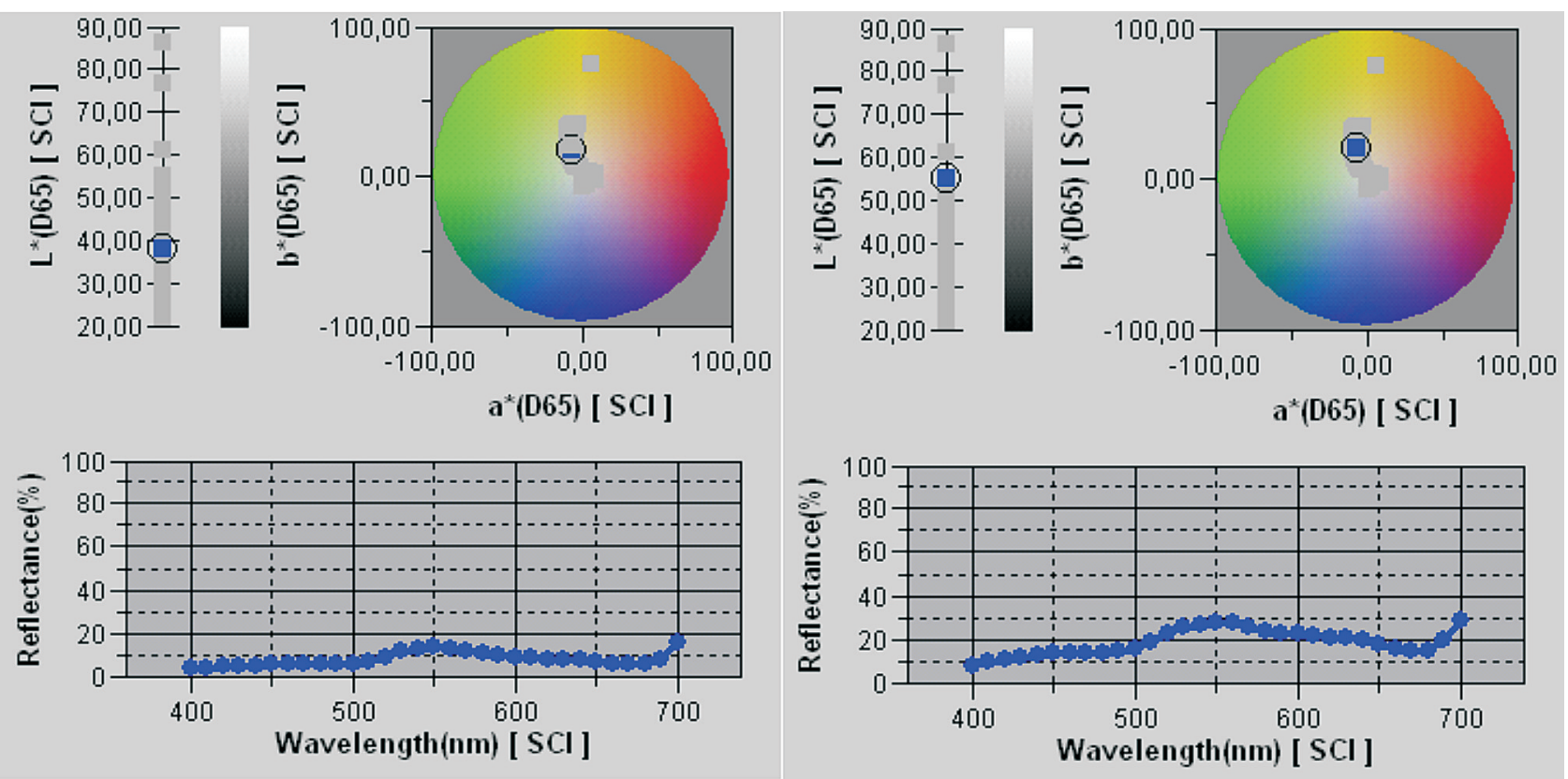

Fig. 1. Chromaticity and brightness of the leaves of Amelanchier alnifolia - top side of the leaf (left), bottom of the leaf (right)

Table 2. The size and firmness of fruits of tested species of Amelanchier

\begin{tabular}{lccc}
\hline \multirow{2}{*}{ Items } & \multicolumn{3}{c}{ Species } \\
\cline { 2 - 4 } & A. alnifolia & A. ovalis & A. spicata \\
\hline Weight of 100 fruits $(\mathrm{g})$ & $98 \mathrm{c}$ & $56 \mathrm{a}$ & $71 \mathrm{~b}$ \\
Diameter of fruit $(\mathrm{mm})$ & $12.5 \mathrm{~b}$ & $7.3 \mathrm{a}$ & $11.9 \mathrm{~b}$ \\
Fruit firmness $\left(\mathrm{G} \mathrm{mm} \mathrm{mm}^{-1}\right)$ & & & \\
$\quad$ at fruit height & $189 \mathrm{a}$ & $254 \mathrm{~b}$ & $226 \mathrm{ab}$ \\
$\quad 100 \mathrm{a}$ & $143 \mathrm{~b}$ & $117 \mathrm{a}$ \\
$\quad$ at fruit diameter & & & \\
Fruit color & $21.4 \mathrm{c}$ & $20.6 \mathrm{~b}$ & $19.3 \mathrm{a}$ \\
$\quad \mathrm{L}^{*}$ & $0.42 \mathrm{a}$ & $0.84 \mathrm{ab}$ & $1.09 \mathrm{~b}$ \\
$\mathrm{a}^{*}$ & $0.20 \mathrm{a}$ & $0.11 \mathrm{a}$ & $-1.08 \mathrm{~b}$ \\
$\mathrm{~b}^{*}$ &
\end{tabular}

Explanation: the means signed with the same letter do not differ significantly at the $5 \%$ level of significance, according to Duncan t-test.

time, the smallest diameter $(7.3 \mathrm{~mm})$. Fruits collected from A. alnifolia bushes were definitely the largest - their weight was higher than that of $A$. ovalis by as much as $75 \%$. The weight of fruits picked from $A$. alnifolia bushes grown under our climatic conditions is similar to fruits collected in Canada (Mazza and Cottrell 2008, Zatylny et al. 2005). Fruit firmness is a characteristic confirming that fruits are suitable for storage and transport. The appearance of serviceberry fruits reminds of chokeberries, they also behave in a similar way during storage. Among the species under analysis, A. ovalis. definitely had the highest firmness, both of the diameter axis and the height. It was also found that fruit firmness in the height axis is higher by $77-89 \%$, compared to the diameter, regardless of the species. Chokeberry fruits in an experiment performed by Skupień et al. (2008) had a similar diame- ter to A. alnifolia fruits, but their firmness was much higher (422-461 G mm).

The harvest time was selected according to the taste and a subjective assessment of the colour, fruits of similar colour were picked. Measurements performed using instruments showed differences in the fruit colour (Table 2). The A. spicata berries were the blackest, they also had the largest number of pigments responsible for the red colour (parameter $a^{*}$ ) and blue (parameter $\mathrm{b}^{*}$ ) (Fig. 2). As indicated by other authors, the black colour of A. alnifolia varieties, determined by the $\mathrm{L}^{*}$ parameter, can range from 14.8 to 21.8 (Zatylny et al. 2005).

On the basis of the extract content, it is possible to assess the sugar content in the fruits. The extract content was the highest in A. alnifolia and A. spicata and it amounted to 14.3 to $14.7 \%$ (Table 3 ). These values are similar to those obtained in other authors research (Zatylny et al. 2002, Zatylny et al. 2005, Rop et al. 2012). The fruits from these species, on the other hand, were characterised by the lowest dry mass con-

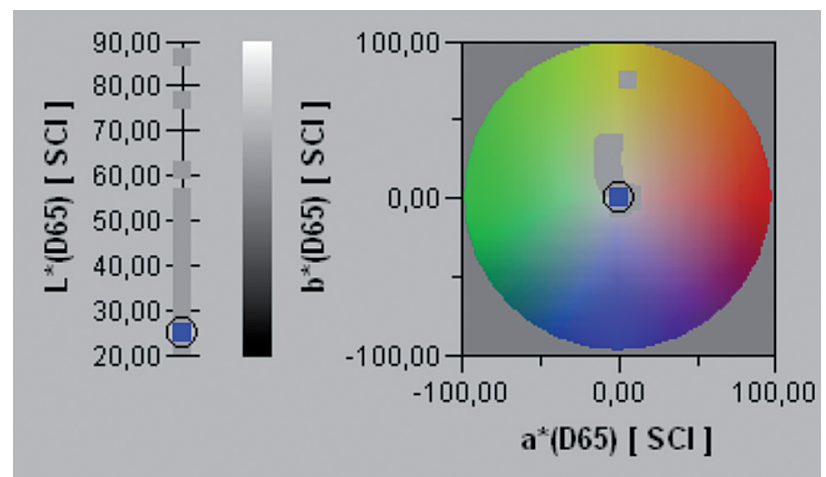

Fig. 2. Chromaticity and brightness of fruits of Amelanchier alnifolia 
Table 3. Chemical composition of tested species of Amelanchier

\begin{tabular}{|c|c|c|c|}
\hline \multirow{2}{*}{ Items } & \multicolumn{3}{|c|}{ Species } \\
\hline & A. alnifolia & A. ovalis & A. spicata \\
\hline Dry matter (\%) & $14.7 \mathrm{a}$ & $16.3 \mathrm{~b}$ & $15.1 \mathrm{a}$ \\
\hline Soluble solids (\%) & $14.3 \mathrm{~b}$ & $12.5 \mathrm{a}$ & $14.7 \mathrm{~b}$ \\
\hline $\begin{array}{l}\text { Titratable acidity } \\
\left(\text { g citric acid } 100 \mathrm{~g}^{-1} \text { ) }\right.\end{array}$ & $0.62 \mathrm{ab}$ & $0.53 \mathrm{a}$ & $0.76 \mathrm{~b}$ \\
\hline Vitamin C (mg $\left.100 \mathrm{~g}^{-1}\right)$ & $5.89 \mathrm{a}$ & $4.16 \mathrm{a}$ & $9.34 \mathrm{~b}$ \\
\hline \multicolumn{4}{|c|}{ Phenols (mg $\left.100 \mathrm{~g}^{-1}\right)$} \\
\hline cyanidin 3-arabinoside & 15.89 & 6.11 & 2.56 \\
\hline cyanidin 3-xyloside & 13.07 & 1.58 & 3.92 \\
\hline cyanidin 3-galactoside & 78.34 & 145.53 & 111.62 \\
\hline cyanidin 3-glucoside & 19.56 & 50.06 & 5.29 \\
\hline Anthocyanins & $126.86 \mathrm{a}$ & $203.28 \mathrm{~b}$ & $123.39 \mathrm{a}$ \\
\hline quercetin 3-galactoside & 10.25 & 15.73 & 1.79 \\
\hline quercetin 3-glucoside & 3.41 & 0.68 & 0.98 \\
\hline quercetin 3-vicianozyd & - & 8.73 & 4.68 \\
\hline quercetin 3-robinobioside & 1.38 & 4.46 & 3.29 \\
\hline quercetin 3-rutinoside & 2.03 & 1.45 & 1.12 \\
\hline quercetin 3-arabinoside & 1.01 & 1.13 & 0.67 \\
\hline quercetin 3-xyloside & 1.56 & 1.08 & 0.97 \\
\hline Flavonols & $19.64 \mathrm{a}$ & $33.26 \mathrm{~b}$ & $13.5 \mathrm{a}$ \\
\hline chlorogenic acid & 43.21 & 30.41 & 24.78 \\
\hline neochlorogenic acid & 9.35 & 12.25 & 4.36 \\
\hline sinapic acid & - & 1.83 & 1.16 \\
\hline ferulic acid & - & 1.11 & - \\
\hline caffeic acid derivatives & 55.78 & 67.27 & 49.22 \\
\hline caffeic acid derivatives & 6.35 & 0.80 & 1.13 \\
\hline caffeic acid derivatives & - & 4.01 & 2.44 \\
\hline caffeic acid derivatives & - & 1.98 & - \\
\hline Acid & $114.69 \mathrm{~b}$ & $119.66 \mathrm{~b}$ & $83.09 \mathrm{a}$ \\
\hline Total & $261.19 \mathrm{~A}$ & $356.20 \mathrm{~B}$ & $219.98 \mathrm{~A}$ \\
\hline
\end{tabular}

tent (14.7-15.1\%). The dry mass content was the highest in A. ovalis fruits and it amounted to $16.3 \%$, while the extract in the fruits from this species was the lowest, at the level of $12.5 \%$. Research by other authors (Bieniek et al. 2002) shows that the dry mass of fruits from this species may even reach $17.2 \%$. A. ovalis fruits also had the lowest organic acid content $(0.53 \mathrm{~g})$. The acid-to-sugar content ratio is responsible for the taste of the fruits, a low acid content affects the subjective perception of high sweetness of the fruits. Hence, serviceberry is popularly called sweet chokeberry. The organic acid content in chokeberries ranges from $0.8 \mathrm{~g}$ to $1.4 \mathrm{~g}$ in $100 \mathrm{~g}$ of fruits, depending on the variety (Ochmian et al. 2009, Ochmian et al. 2012). Fruits of the species under analysis from the Amelanchier genus were characterised by a low vitamin $\mathrm{C}$ content, as compared to other berry species. However, the most vitamin $\mathrm{C}$ was found in berries collected from the A. spicata bush $(9.34 \mathrm{mg})$, while the content of this ingredient in A. alnifolia and A. ovalis was lower by $37 \%$ and $55 \%$ respectively. Bieniek et al. (2002) claim that the content of ascorbic acid in snowy mespilus fruits can be higher than $16 \mathrm{mg} 100 \mathrm{~g}^{-1}$.

The research has shown that the fruits of the individual species differed in terms of their chemical composition and polyphenol content. A. ovalis was characterised by the highest polyphenol content, both from anthocyanins and flavonols group. The polyphenol content was at a similar level in the remaining species. In studies Jurikova et al. (2012) content of various quercetins in fruits of A. alnifolia was at a similar level, while chlorogenic acid content was several times greater. The total anthocyanin content in fruit of A. alnifolia varied between 258.7 and $517.9 \mathrm{mg} / 100$ fresh weight among cultivars (Lavola et al. 2012). The total phenolic acid content of $A$. alnifolia was $191.4 \mathrm{~g}$ fresh fruit and that of $A$. spicata $209.1 \mathrm{mg} / 100 \mathrm{~g}$ (Sergeeva et al. 1980). Fruits studied species of the genus Amelanchier were significantly less rich in polyphenolic compounds than fruit chokeberry (Ochmian et al. 2012 b) but contained much more of these compounds than fruit of blue honeysuckle (Ochmian et al. 2012).

\section{Conclusions}

1. The species under analysis from the Amelanchier genus were different from each other, both in terms of their morphological features and the quality and chemical composition of the fruits. However, all of them were characterized by very low acidity and a very low vitamin $C$ content.

2. From among the assessed species, Amelanchier ovalis was characterised by the smallest fruits, however, they were firmer and were characterised by the highest polyphenol content, both from the groups of anthocyanins and flavonols.

3. The Amelanchier spicata species was characterised by the smallest and the greenest leaves and relatively large and firm fruits with high extract content, but a low content of polyphenols and organic acids.

4. Amelanchier alnifolia has large lanceolate yellow and green leaves and large fruits with the lowest firmness from among all the species. In terms of the polyphenol content, this species is similar to Amelanchier spicata

\section{References}

Adhikari D.P., Francis J.A., Schutzki R.E, Chandra A. Nair M.G. 2005. Quantification and characterisation of cyclooxygenaseand lipid peroxidation inhibitory anthocyanins in fruits of Amelanchier. Phytochemical Analysis 16: 175-180. 
Bakowska-Barczak A., Kolodziejczyk P. 2008. Evaluation of Saskatoon Berry (Amelanchier alnifolia Nutt.) Cultivars for their Polyphenol Content, Antioxidant Properties, and Storage Stability. Journal of Agricultural and Food Chemistry 56: 9933-9940.

Bieniek A., Kawecki Z., Piotrowicz-Cieslak A.I. 2002. Zawartość niektórych składników organicznych W owocach mniej znanych roślin sadowniczych. Biuletyn Naukowy. Uniwersytet Warmińsko-Mazurski w Olsztynie 14 pp. 11-17.

Binggeli P. 1988. Plants of the Pacific Northwest in Western Europe. Botanical Electronic News 195.

Finn C. 1999. Temperate berry crops. In: Perspectives on New Crops and New Uses; Janick J., (ed.); ASHS Press: Alexandria, VA, pp. 324-334.

Gregorczyk A., Raczyńska A. 1997. Badania korelacji między metodą Arnona a pomiarami zawartości chlorofilu za pomocą chlorofilometru. Zeszyty Naukowe AR Szczecin 181: 119-123.

Han X., Shen T., Lou H. 2007. Dietary polyphenols and their biological significance. International Journal of Molecular Sciences 8: 950-988.

Jurikova T., Sochor J., Rop O., Mlček J., Balla S., Szekeres L., Žitný R., Zitka O., Adam W., Kizek R. 2012. Evaluation of polyphenolic profile and nutritional value of non-traditional fruit species in the Czech Republic - A Comparative Study. Molecules 17: 8968-8981.

Kubus M. 2003. Rare species of trees and shrubs of tree nursery in Danowo near Goleniów. Rocznik. Dendrologiczny 51: 99-111.

Kuusk V., Tabaka L., Jankevičiene R. 1996. Flora of the Baltic countries. Eesti Loodusfoto AS, Tartu, pp. 372 .

Lavola A., Karjalainen R., Julkunen-Tiitto R. 2012. Bioactive Polyphenols in Leaves, Stems, and Berries of Saskatoon (Amelanchier alnifolia Nutt.) Cultivars. Journal of Agricultural and Food Chemistry 60: 1020-1027.

Łuczaj Ł. 2004. Dzikie rośliny jadalne Polski, przewodnik survivalowy. Wyd. drugie poszerzone. Chemigrafia, Krosno.

Mazza G. 1982. Chemical composition of Saskatoon berries (Amelanchier alnifolia Nutt.). Journal of Food Science 47: 1730-1731.

Mazza G. 2005. Compositional and functional properties of Saskatoon berry and blueberry. International Journal of Fruit Science 5: 101-120.

Mazza G., Cottrell T. 2008. Carotenoids and cyanogenic glucosides in saskatoon berries (Amelanchier alnifolia Nutt.). Journal of Food Composition and Analysis 21: 249-254.
Mazza G. Davidson C. 1993. Sasakatoon berry: A fruit crop for the prairies. In: J. Janick and J.E. Simon (eds.), New crops. Wiley, New York, pp. 516-519.

Ochmian I., Oszmiański J., Skupień K. 2009. Chemical composition, phenolics and firmness of small black fruits. Journal of Applied Botany and Food Quality 83: 64-69.

Ochmian I., Grajkowski J., Smolik M. 2012. Comparison of some morphological features, quality, and chemical content of four cultivars of chokeberry fruits (Aronia melanocarpa). Notulae Botanicae Horti Agrobotanici Cluj-Napoca 40: 253-260.

Ochmian I., Skupień K., Grajkowski J., Smolik M., Ostrowska K. 2012 b. Chemical composition and physical characteristics of fruits of two cultivars of blue honeysuckle (Lonicera caerulea L.) in relation to their degree of maturity and harvest date. Notulae Botanicae Horti Agrobotanici Cluj-Napoca 40: 155-162.

Pacewicz K., Gregorczyk A. 2009. Porównanie ocen zawartości chlorofilu chlorofilometrami SPAD-502 i N-Tester. Folia Pomeranae Universitatis Technologiae Stetinensis. Agricultura, Alimentaria, Piscaria et Zootechnica 269: 49-46.

Pirs R. 2000. Korinte kâ kultûraugs. Dârzs un drava 10(491): 4-6.

Rop O., Zenek V., Mlcek J., Juríková T., Sochor J., Kizek R., Humpolícek P., Balík J. 2012. Nutritional values of new Czech cultivars of Saskatoon berries (Amelanchier alnifolia Nutt.) Horticultural Science 39: 123-128.

Seneta W. 1991. Drzewa i krzewy liściaste A-B. Wydawnictwo Naukowe PWN Warszawa, pp. 208-217.

Sergeeva N.V., Bandyukova V.A., Shapiro D.K., Narizhnaya T.I., Anikhimovskaya L. V. 1980. Phenolic acids in the fruits of some Amelanchier species. Khimiya Prirodnykh Soedinenii 5: 726-728.

Skupień K., Ochmian I., Grajkowski J. 2008. Influence of mineral fertilization on selected physical features and chemical composition of aronia fruit. Acta Agrophysica 11: 213-226.

Zatylny A.M., St-Pierre R.G., Tulloch H.P. 2002. Comparative agronomic performance of 15 saskatoon (Amelanchier alnifolia Nutt.) cultivars during their first seven years of growth. Journal of American Pomological Society 56: 118-128.

Zatylny A.M., Ziehl W.D., St-Pierre R.G. 2005. Physicochemical properties of fruit of 16 saskatoon (Amelanchier alnifolia Nutt.) cultivars. Canadian Journal of Plant Science 85: 933-938. 